DOI: https://doi.org/10.18371/fp.3(39).2020.215182

УДК 338.43

\title{
ІННОВАЦІЙНА СТРАТЕГІЯ РОЗВИТКУ АГРАРНИХ ПІДПРИЄМСТВ
}

\author{
КОВТУН Валентина Андріївна \\ кандидат сільськогосподарських наук, доцент, \\ дочент кафедри економіки та фінансів \\ ДВНЗ «Херсонський ДАУ» \\ ORCID ID: http://orcid.org/0000-0002-4275-026X \\ e-mail:vak2901@ukr.net
}

\begin{abstract}
Анотація Інновачійна стратегія діяльністю аграрних підприємств спрямовується на пошук та реалізацію інновачійних проєктів, які забезпечать стабільний і прибутковий розвиток суб'єкта господарювання в довгостроковій перспективі. Вибір найдієвішої інноваційної стратегії залежить від базової стратегії підприємства, його поточного стану та конкурентного середовища, тобто від сукупності внутрішніх $i$ зовнішніх умов. У статті зазначається, щзо в Україні розпочався новий етап розвитку сільського господарства, який характеризується збільшенням обсягів використання інноваційних технологій. Встановлено, щзо ефективними для аграрїв $\epsilon$ інновачійні платформи, які працюють у сфері big data, як: БАЙЕР БІЗHEC ПЛЮС, AGRIANALYTICA, SAATBAU PROFIT MANAGER momo.
\end{abstract}

Ключові слова: інноващіï, стратегія, аграрні підприємства, інноваційні платформи, економічний ефект.

Постановка проблеми. Розвиток будь-якого аграрного підприємства неможливий без розробки стратегічних напрямів діяльності інноваційного характеру. Інноваційна стратегія розвитку аграрного підприємства включає використання науково - технічних досягнень у сфері організації управління, техніки й технології та компле-
Аннотация. Инновачионная стратегия деятельности аграрных предприятий направляется на поиск и реализацию инноваиионных проектов, которые обеспечат стабильный и прибыльный развитие предприятия в долгосрочной перспективе. Выбор действенной инновационной стратегии зависит от базовой стратегии предприятия, его текущего состояния и конкурентной среды, то есть от совокупности внутренних и внешних условий. В статье отмечается, что в Украине начался новый этап развития сельского хозяйства, который характеризуется увеличение объемов использования инноващионных технологий. Установлено, что эффективными для аграриев есть инновационные платформы, которые работают в сфеpe big data, как: БАЙЕР БИЗНЕС ПЛЮС, AGRIANALYTICA, SAATBAU PROFIT MANAGER и другие.

Ключевые слова: инновации, стратегия, аграрные предприятия, инновачионные платформы, экономический эффект.

ксний підхід до інноваційної діяльносTi.

Аналіз останніх досліджень і публікацій. Проблематика інноваційного розвитку аграрних підприємств $\epsilon$ актуальною серед науковців, зокрема: В.Г. Андрійчук, В.Я. Амбросов, Н.О. Афендікова, В.О. Білінська, А.А. Гребеннікова, О.I. Донець, О.В. Кривешко, М.Й. Малік, О.Т. Ма- 
лій, А.В. Нєлепова, В.М. Орлова, Т.В. Писаренко, T.P. Побережна, П.Т. Саблук, П.В. Сідун, Н.М. Сіренко, Н.Т. Тверезовська, С.I. Тищенко, O.I. Шаманська, О.Г. Шпикуляк та інших. Це пояснюється тим, що аграрним підприємствам необхідно активно шукати та впроваджувати високоякісні інноваційні рішення, які здатні підвищити обсяг виробництва, переробки та реалізації продукції з високим економічним ефектом.

Метою дослідження $\epsilon$ аналіз сучасного стану інноваційного забезпечення аграрних підприємств та його впливу на ефективне використання їх ресурсів, обгрунтування важливості розробки інноваційної стратегії розвитку аграрних підприємств та ефективного механізму використання інноваційних технологічних рішень для отримання економічного та соціального ефекту.

Виклад основного матеріалу. Значення інноваційного розвитку для регіонів важко переоцінити, тільки через інновації можна забезпечити конкурентоспроможність продукції як на вітчизняному, так і на світовому ринках. Ефективне використання інновацій стає вирішальним фактором соціально-економічного розвитку i розв'язання економічних, екологічних, соціальних та інших проблем.

В умовах України багато аграрних підприємств в недостатній мірі використовують інструменти інноваційного управління для посилення свого конкурентного потенціалу. Зміна тенденцій у аграрному виробництві відбувається настільки швидко, що навіть найбільш прогресивним підприємствам важко передбачити стійкі конкурентні переваги свого майбутнього розвитку. Інноваційний розвиток ви- ступає ефективним інструментом вирішення проблем підвищення конкурентоспроможності аграрних підприємств і $є$ одним з ключових напрямків стратегічного та тактичного управління підприємством [1].

Однією $з$ найбільш перспективних сфер світового бізнесу сьогодні є сільське господарство. Провідні аграрні підприємства активно шукають та впроваджують високоякісні інноваційні рішення. Інноваційні стратегії базуються на оцінці стратегічних чинників зовнішнього та внутрішнього середовища, що впливають на процеси аграрного виробництва, основними 3 яких є організаційні особливості підприємств сфери виробництва, стан ринків, можливість впровадження інновацій, конкурентна ситуація, стан інвестиційної політики як підприємств по виробництву, переробці, реалізації аграрної продукції так і держави в ціломy [2].

Головною стратегією інноваційного розвитку аграрних підприємств повинна бути стратегія глобалізації, яка складається 3 декількох стратегічних складових із обов'язковими екологічними, технологічними компонентами та стратегією бізнес-планування інноваційного розвитку. Основні напрямки стратегії інноваційного регіонального розвитку є: цільовий ринок, позиція та асортимент аграрної продукції, ціноутворення, реклама, стимулювання переробки та збуту продукції, тощо. Інновацією у розвитку аграрних підприємств є зміни в техніці, технології, організації, екології, економіці, а також у соціальній сфері задля одержання економічного ефекту, спрямованого на задоволення певних суспільних потреб. Взаємозв'язок стратегії інноваційного розвитку з іншими стратегія- 
ми розвитку аграрних підприємств ві- дображено на рис. 1.

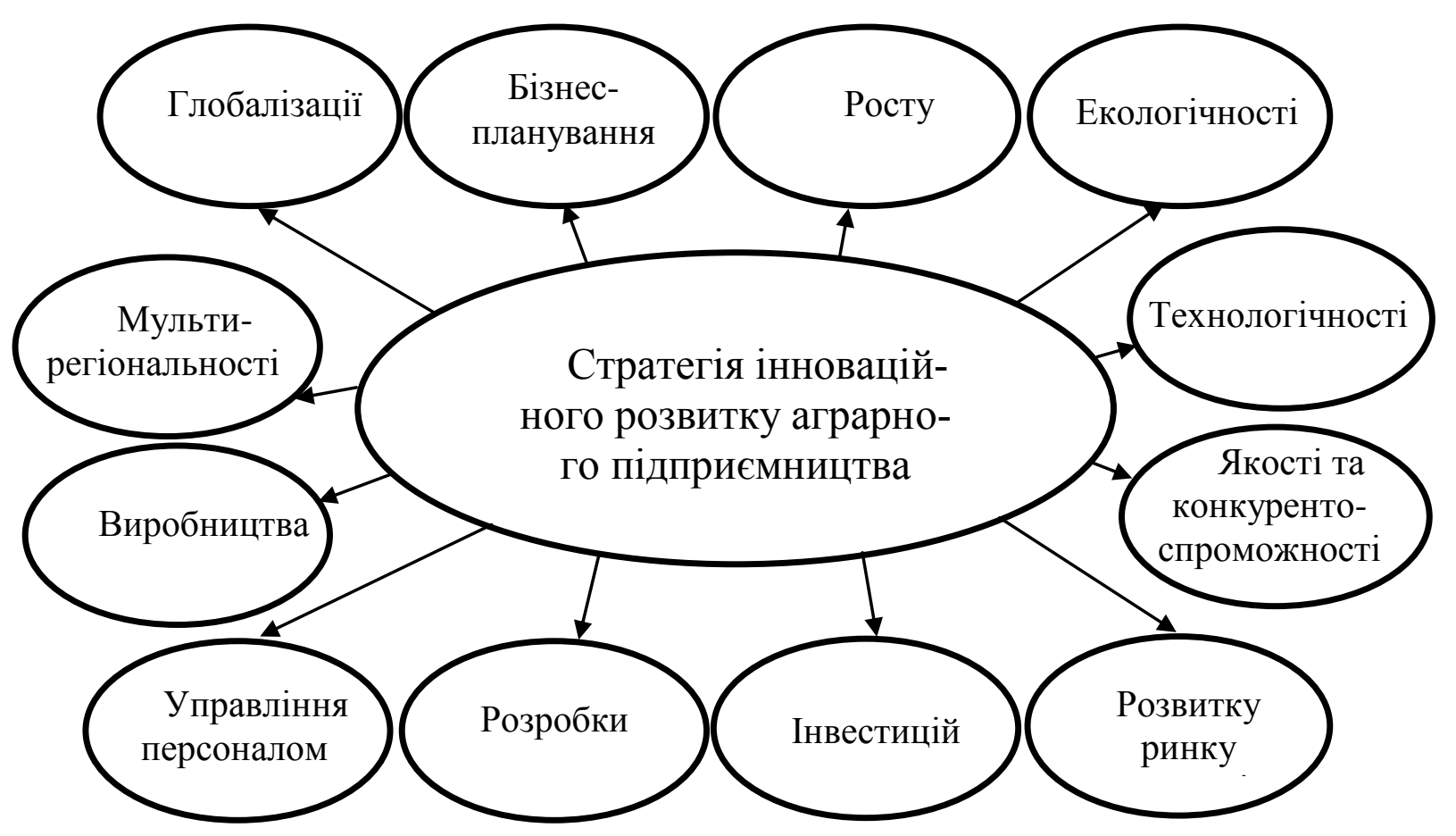

Рис. 1. Взаємозв'язок стратегії інноваційного розвитку з іншими стратегіями розвитку аграрних підприємств Джерело: побудовано на основі [3]

Сьогодні головною метою державної інноваційної політики є створення соціально-економічних, організаційних і правових умов для ефективного відтворення, розвитку й використання науково-технічного потенціалу країни, забезпечення впровадження сучасних екологічно чистих, безпечних, енергота ресурсозберігаючих технологій, виробництва й реалізації нових видів конкурентоспроможної продукції. Стратегія інноваційного розвитку аграрних підприємств - це сукупність дій та методів ведення інноваційної діяльності, що має свою специфіку та забезпечує конкурентні переваги за рахунок інновацій. Основу інноваційного потенціалу підприємства складають кадрові та матеріально-технічні складові, а також наявність науковотехнічної й інтелектуальної власності. Особливо важливою $є$ наявність кад- рів - спеціалістів і вчених, що забезпечують інноваційний процес новими знаннями, ідеями, винаходами, ноухау, новими технологіями.

Інноваційна стратегія розвитку аграрних підприємств передбачає системний підхід до освоєння інновацій. Інноваційний потенціал розглядається як:

1) сукупність ресурсів, необхідних для здійснення інноваційної діяльносTi;

2) сукупність активів, що використовуються в інноваційній діяльності;

3) можливості підприємства, що визначають обсяги, терміни, кількість i якість його інноваційної діяльності;

4) здатність підприємства проявляти інноваційну активність;

5) міра готовності їх до здійснення інноваційної активності; 
6) складна динамічна система, що здійснює інноваційну діяльність;

7) характеристика потоку нововведень;

8) складова інтелектуального потенціалу;

9) певна структура його складових;

10) одна 3 трьох складових інноваційного простору.

Він $є$ складною динамічною системою генерування, накопичення і трансформування наукових, управлінських ідей та науково-технічних, маркетингових результатів і інноваційні продукти на основі здійснення безперервного управління аграрним підприємством [4, с. 69].

Стратегічне управління інноваційною діяльністю аграрних підприємств спрямовується на пошук і реалізацію інноваційних проєктів, які забезпечать стабільний та прибутковий розвиток суб'єкта господарювання в довгостроковій перспективі. Виконуючи цю функцію, менеджери аграрних підприємств повинні розробити власну інноваційну стратегію, яка дасть змогу пристосуватися до змінних зовнішніх умов, та визначити час для іiі реалізації. Вибір найдієвішої інноваційної стратегії залежить від базової стратегії підприємства, його поточного стану та конкурентного середовища, тобто від сукупності внутрішніх і зовнішніх умов.

Правильно обрана стратегія $\epsilon$ найважливішим результатом i ефективним механізмом стратегічного управління, оскільки вона мобілізує використання науково-технічного, фінансово-економічного, соціального і організаційного потенціалу аграрного підприємства в певних напрямах. Першочерговим завданням постає визначення пріоритетних напрямів розвитку підприємства, забезпечення конкурентоспроможності продукції та підвищення ефективності виробництва. Незважаючи на те, що стратегія інноваційного розвитку відкриває нові можливості, для більшості аграрних підприємств завдання стратегічного планування інноваційного розвитку є досить новим.

Для вдосконалення аграрної політики необхідним $є$ врахування інноваційної компоненти, що дасть можливість посилити внутрішні індикатори господарської діяльності аграрних підприємств на основі формування технологічних, агротехнічних та організаційно-економічними можливостей у інноваційному напрямі. Однією із головних причин низької інноваційної активності вітчизняних аграрних підприємств $€$ відсутність механізмів та інструментів зацікавленості у впровадженні інноваційних розробок у аграрне виробництво [5, с. 33].

Можна виділити три стратегічні напрями ресурсно-технологічного оновлення аграрного сектору: створення i застосування технологій і біоресурсів, що сприяють здешевленню вироблюваної продукції; розробка та впровадження технологій i біоресурсів, які дають можливість істотно підвищити якість продуктів харчування та аграрної сировини; створення та використання технологій і основних біологічних засобів виробництва, що забезпечують випуск екологічно чистого продовольства й екологічну аграрну діяльність, переробку їі продукції [6, с.18].

Здійснення ефективної інноваційної діяльності аграрних підприємств можливо лише за допомогою державної підтримки, яка має здійснюватися через систему економічних механізмів 
та важелів. Концептуальну модель формування стратегіï інноваційноінвестиційного розвитку підприємств аграрної сфери, де ключовою складовою $є$ чітке формулювання та визначення цілей діяльності аграрного підприємства, що забезпечить формулювання вірних інноваційних орієнтирів на різних стадіях діяльності. Формування стратегії інноваційноінвестиційного розвитку дасть можливість підвищити конкурентоспроможність продукції агропідприємств, забезпечити стійкі позиції на ринку та підвищити ефективність їх функціонування [7, с 125].

Аграрним підприємствам необхідний новий підхід до організації внутрішнього планування. Для залучення іноземних інвесторів необхідним є бізнес-план, який би відповідав міжнародним стандартам і був адаптований до наших умов. В процесі бізнеспланування найбільш широко необхідно застосовувати програми Comfar (UNIDO), Project Expert, пакети компаній „ІНЕК” та „Альт-Інвест”, Project Manager, Success та інші. Агропромисловий сектор економіки України для впровадження інноваційних розробок потребує щорічних інвестицій не менше 75 млрд грн [8, с. 602].

Інноваційна діяльність у сільському господарстві - це комплексний процес створення нових або більш продуктивних високоврожайних сортів, поголів'я худоби, елітного насіння, високопродуктивних сільськогосподарських машин i агрегатів тощо, впровадження прогресивних технікотехнологічних, організаційно-економічних й управлінських рішень, комерціалізація сучасних споживчих норм Щоб створити сприятливі умови для інноваційного розвитку аграрного біз- несу в Україні, потрібно ліквідувати фінансову нестабільність сільського господарства, що стримує фінансових інвесторів. Заходи щодо фінансового оздоровлення підприємств АПК повинні стати пріоритетними в державній аграрній політиці [9].

Впровадження сучасних систем землекористування та інформаційних агротехнологій вимагають розробки та впровадження інноваційних інформаційних технологій. До таких систем можна віднести Global Positioning System (GPS), "Rapid Eye", CORINE Land Cover (Coordination of Information on the Environment). Встановлено, що ефективними для аграріїв $\epsilon$ інноваційні платформи, які працюють у сферi big data такі продукти як: БАЙЕР БІЗНЕС ПЛЮС, AGRIANALYTICA, SAATBAU PROFIT MANAGER тощо. Грунтовокліматичні умови України дають змогу значно розширити обсяги органічного землеробства, які за експертними оцінками можуть досягти 7 \% сільськогосподарських угідь у 2020 році. Програми ГЕО-Агро, ГІС Панорама Землеробство, Farm Works Site (Pro), SST Summit, SMS Desktop Software (Advanced i Basic), JD Reports MAP, АграрOфic, Agro-Net NG, FarmView Record Keeper та інші дають можливість автоматичного розрахунку потреби в насінні, добривах та засобах захисту рослин, а також забезпечують функцію ефективного управління земельними, виробничими, трудовими та фінансовими ресурсами аграрних підприємств.

Великі можливості ефективного використання ресурсів аграрних підприємств відкриває застосування смартфонів та мобільних додатків, які можуть здійснювати: відстеження та ко- 
нтроль транспортних засобів; контроль водіїв; нагадування й попередження; супровід i підтримку через такі програми, як: ГЕО-Обліковець, ГЕОПлан, Кишеньковий вимірювач, Агронавт, Farm Works Mobile, SST Stratus, SMS Mobile, AGROGPS Mobilbox та інші [10].

Інноваційні технологічні рішення дозволяють максимально зменшити залежність від природних умов, використовувати особливості погоди на користь розвитку рослин, автоматизувати систему поливу, планувати внесення добрив на основі хімічного аналізу вмісту поживних речовин кожного поля, здійснювати моніторинг наявності шкідників та планувати внесення інсектицидів при перевищенні порогу їх шкідочинності тощо. По-

ліпшення агротехнічних робіт забезпечить заощадження мінеральних добрив на 13,9 млрд грн на рік. Впровадження ресурсозберігаючих i мінімальних технологій обробітку грунту Mini-till, No-till aбo Zero-till тa Strip-till мають схожі проблеми в адаптації до вітчизняних умов господарювання. Це слабка державна підтримку, значні фінансові витрати, необхідність заміни машинно-тракторного парку та використання сучасних інформаційних технологій. Економічний ефект від запровадження мінімального обробітку грунту в 2020 році становитиме 6,3 млрд грн [11 с.77].

Ефективність впровадження інноваційних агротехнічних заходів у рослинництві наведена в табл. 1.

Таблиця 1

Ефективність впровадження пріоритетних заходів у рослинництві

\begin{tabular}{|c|c|c|c|}
\hline \multirow{2}{*}{ Види заходів } & \multicolumn{2}{|c|}{ Роки } & \multirow{2}{*}{$\begin{array}{c}\text { Темп росту } \\
\%\end{array}$} \\
\hline & 2015 & 2020 & \\
\hline \multicolumn{4}{|l|}{ Біологізація } \\
\hline Внесення органічних добрив, млн. т. забезпечить: & 57,9 & 105 & 181,3 \\
\hline - приріст гумусу, тис. т & 2606 & 4725 & 181,3 \\
\hline - надходження NPK, тис. т. & 1186 & 2098 & 176,9 \\
\hline \multicolumn{4}{|c|}{ Запровадження науково-обгрунтованих сівозмін } \\
\hline -посіви багаторічних трав , млн. га. & 1,8 & $1, .9$ & 105,6 \\
\hline - бобових культур, млн. га. & 2,3 & 2,8 & 121,7 \\
\hline забезпечить: - щорічне утворення гумусу, тис. т. & 3680 & 3760 & 102,2 \\
\hline - фіксації біологічного азоту, тис. т. & 496 & 502 & 101,2 \\
\hline -економію мінеральних добрив, млн. грн. & 4960 & 5020 & 101,2 \\
\hline \multicolumn{4}{|c|}{ Розширення посівів сидеральних культур } \\
\hline Площа посівів, млн. га забезпечить: & 1,5 & 2,0 & 133,3 \\
\hline - утворення гумусу, тис. т. & 1350 & 1800 & 133,3 \\
\hline - надходження NPK, тис. т. & 251 & 342 & 136,2 \\
\hline - економію мінеральних добрив, млн. грн. & 1960 & 2620 & 133,7 \\
\hline
\end{tabular}


Завершення табл. 1

\begin{tabular}{|l|c|c|c|}
\hline \multicolumn{4}{|c|}{ Використання на добрива побічної продукції рослинництва } \\
\hline Обсяг побічної продукції, млн. т забезпечить: & 28,8 & 37,5 & 130,2 \\
\hline - утворення гумусу, тис. т. & 4296 & 5513 & 128,3 \\
\hline - надходження NPK, тис. т. & 630 & 820 & 130,2 \\
\hline - економію мінеральних добрив, млн. грн. & 4920 & 6280 & 127,6 \\
\hline
\end{tabular}

Джерело: [11, с.78]

Галуззю аграрної сфери, що потребує значних інвестицій i на даному етапі розвитку знаходиться в кризовому стані, є тваринництво. Воно стимулює суб'єктів господарювання до модернізації, технологічної оснащеності та провадження новітніх інтелектуальних рішень. Для галузі тваринництва при ефективному використанні ресурсного іiі потенціалу можливості сучасних інформаційних систем дозволяють: підтримувати оптимальний мікроклімат у приміщеннях із тваринами; відстежувати динаміку їх здоров'я, приросту маси тварин та відповідності показників нормативним критеріям; автоматизувати планування структури стада; враховувати генеалогію та біологічні цикли при плануванні розмноження тварин; формувати автоматизовано раціон їх харчування; автоматизувати план ветеринарних заходів. Суть інноваційних технологій це впровадження, в першу чергу біотехнологій iз застосуванням методів клітинної та генної інженерії у підвищенні відтворювальних функцій тварин та в перспективі створення вітчизняного ринку племінних ресурсів, який би повністю забезпечив внутрішню потребу та орієнтувався на експорт.

Сучасні норми годівлі повинні враховувати потреби тварин в енергії, сухій речовині, протеїнах, вуглеводах, клітковині, жирі, мікроелементах, ка- ротині, вітамінах методом створення різноманітних їх режимів стосовно відповідних порід тварин через точність їх дозування. Технікотехнологічне забезпечення, що характеризується оновленням технологічної бази ферм новітнім обладнанням для утримання тварин досить слабка. Через відсутність організаційноекономічної, фінансової та матеріально-технічної підтримки для впровадження ресурсозберігаючих технологій, що базуються на повній автоматизації процесу, використанні робототехніки, створенні кормової бази, розведенні високопродуктивного поголів'я відсутні. Основним завданням для галузі тваринництва, завдяки впровадженню інноваційних технологій, $\epsilon$ збільшення виробництва валової продукції у 2020 році до 83,4 млрд грн, що майже в 2 рази більше 2010 року, а також збільшення обсягів виробництва м'яса в забійній масі у 2020 році до 4365 тис. т., або темп приросту цього показника буде становити 112,0% [12, c. 80].

Висновки. Розробка програми інноваційного розвитку та відповідної стратегії $\epsilon$ базою формування конкурентних переваг і стійкого фінансового стану вітчизняних аграрних підприємств. Для прийняття раціональних стратегічних управлінських рішень у аграрних підприємствах для покращення їх інноваційного розвитку су- 
часні технології дозволяють виявляти недоліки та ризики в технологічних процесах. Впроваджуючи в діяльність аграрних підприємств інноваційні технології, інвестиційні кошти працюють не тільки на стратегічні плани, а i на їх тактичні можливості, заощаджуючи земельні, виробничі, трудові та фінансові ресурси.

Правильно обрана інноваційна стратегія є найважливішим результатом і ефективним механізмом стратегічного управління. Вона мобілізуе використання науково-технічного, фінансово-економічного, соціального і організаційного потенціалу підприємства. Першочерговим завданням постає визначення пріоритетних напрямів розвитку підприємства, забезпечення конкурентоспроможності продукції та підвищення ефективності виробництва.

Перспективи подальших розробок у цьому напрямку заключаються в тому, що незважаючи на те, що стратегії інноваційного розвитку відкривають нові можливості, для більшості аграрних підприємств завдання стратегічного планування інноваційного розвитку $\epsilon$ досить новим. Тому побудова стратегії інноваційного розвитку підприємства повинна бути забезпечена удосконаленою правово-методичною базою та інвестиційними коштами для вибору оптимального варіанту інновацій, впровадження в підприємство, стабільність та інтенсивний тип розвитку цих суб'єктів господарювання.

\section{Список використаної літератури}

1. Ковтун В.А. Методологічні та методичні підходи до стратегії інноваційноінвестиційного розвитку аграрних підприємств МНПК «Філософські обрії сьогодення», Херсон , ДВНЗ «ХДАУ»., 2019. С.80-84.

2. The global innovation index 2017. Innovation feeding the world/Soumitra Dutta, Bruno Lanvin, and Sacha Wunsch-Vincent URL: http://www.wipo.int/ edocs/pubdocs/en/wipo_pub_gii_2017.pdf (дата звернення 09.09.2020).

3. Гребеннікова А.А. Розвиток сільського господарства на інноваційній осно-

вi. URL: http://www.economy.nayka.com.ua/?op=1\&z=5338 (дата звернення 09.09.2020).

4. Ковтун В.А. Інноваційний та фінансовий ресурсний потенціал аграрних підприємств. Фінансовий простір. № 2 (№34) С. 62-73.

5. Афендікова Н.О. Інноваційний розвиток аграрного виробництва в сучасних умовах. Економіка та держава.№ 6, 2016. С. 32-34.

6. Писаренко Т.В. Стан інноваційної діяльності та діяльності у сфері трансферу технологій в Україні у 2017 році: аналітична довідка. К.: УкрIHTEI, 2018. $98 \mathrm{c}$.

7. Шаманська О. І. Формування системи інноваційно-орієнтованого розвитку аграрних підприємств. Ефективна економіка. № 12, 2016. С. 123-128. 
8. Ковтун В.А. Стан та перспективи інвестиційного забезпечення галузі сільського господарства України. МНПІК. Сучасний рух науки,Way Science. Дніпpo, 2018. C.599-604.

9. Тверезовська Н.Т., Нєлепова А.В. Інформаційні технології в агрономiï. 2017 p. URL: https://pidruchniki.com/1337101861366/informatika/rozvitok_vpr ovadzhennya_informatsiynih_tehnologiy_silskomu_gospodarstvi (дата звернення 09.09.2020).

10. Tanklevska N., Kovtun V. The intelligent technological solutions as a tool of efficient use of the agriculture resources. Науковий вісник Льотної академії. Серія: Економіка, менеджмент та право. 2019. С.64-72.

11. Білінська В. Сучасні інноваційні технології в сільському господарстві: основна характеристика та перспективи впровадження. Вісник Київського наиіонального університету імені Тараса Шевченка. Економіка. 2015 р. Вип. 7 (172). C. $75-81$.

12. Ковтун В.А. Роль інтелектуальних технологічних рішень для ефективного використання ресурсів сільського господарства. Східна Свропа: економіка, бізнес та управління. 2019. №1(18). URL: http://www.easterneurope-ebm.in.ua/182019-ukr (дата звернення 09.09.2020). 